\title{
First record of Pachydiscus noetlingi Kennedy, 1999 (Ammonoidea) from the Maastrichtian type area (the Netherlands)
}

\section{J.W.M. Jagt ${ }^{1} \&$ W.J. Kennedy ${ }^{2}$}

${ }^{1}$ Natuurhistorisch Museum Maastricht, P.O. Box 882, NL-6200 AW Maastricht, the Netherlands; e-mail: john.jagt@maastricht.nl

2 Oxford University Museum of Natural History, Parks Road, Oxford OX1 3PW, United Kingdom; e-mail: Jim.Kennedy@earth.ox.ac.uk

Manuscript received: January 2001; accepted: May 2001

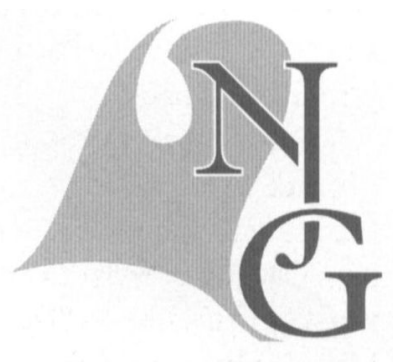

\begin{abstract}
Two specimens of a pachydiscid ammonite, a fragmentary silicified phragmocone from the Kunrade Limestone facies at Kunrade (Schunck), and a partial external mould preserved in flint from the Nekum Member (both Maastricht Formation, Belemnitella junior Zone of authors) at the former Blom quarry (Berg en Terblijt), are identified as Pachydiscus (P.) noetlingi Kennedy, 1999, a species previously known only from the Upper Maastrichtian of Baluchistan (Pakistan). This new record underscores the proposal of incursions of Tethyan biota into the type area of the Maastrichtian Stage, previously documented for other groups, including echinoderms and bivalves, as well.
\end{abstract}

Keywords: ammonites, Maastrichtian, Late Cretaceous, the Netherlands, faunal incursions

\section{Introduction}

To date, 55 species of ammonite have been recorded from the extended type area of the Maastrichtian Stage (Fig. 1) (for details see Jagt, 2002), and amongst these pachydiscids are the best represented group, with at least 12 named species. The Vaals Formation (lower Lower-lower Upper Campanian) contains Pachydiscus (P.) duelmensis (Schlüter, 1872), $P$. (P.) launayi de Grossouvre, 1894, Eupachydiscus levyi (de Grossouvre, 1894), P. (P.) subrobustus Seunes, 1892 , and $P$. (P.) colligatus (Binkhorst, 1861), as documented by Jagt (1989), Jagt et al. (1995) and Kennedy \& Jagt (1998).

The Zeven Wegen Member (Gulpen Formation, lower/middle Upper Campanian) has yielded $P$. (P.) haldemsis (Schlüter, 1867), while the Vijlen Member (Gulpen Formation, upper Lower-lower Upper Maastrichtian) contains $P$. (P.) neubergicus (von Hauer, 1858), P. (P.) aff. armenicus Atabekian \&
Akopian, 1969, and P. (P.) sp. sensu Jagt (in Jagt et al., 1995), as discussed by Jagt (2001) and Jagt $\&$ Felder (2002).

Within the Maastricht Formation, the Kunrade Limestone facies and the Emael, Nekum and Meerssen members (lower-upper Upper Maastrichtian) have yielded $P$. (P.) gollevillensis (d'Orbigny, 1850), $P$. (P.) j. jacquoti Seunes, 1890, 'Menuites'fresvillensis (Seunes, 1890), and ' $M$.' terminus (Ward \& Kennedy, 1993). To this list is added the present record of $P$ (P.) noetlingi.

\section{Geographic and stratigraphic setting}

The best preserved specimen (Fig. 2B, C), a fragmentary phragmocone remarkable for being entirely silicified, is from the so-called Kunrade Limestone facies (Maastricht Formation) at the disused Schunck quarry (see W.M. Felder, 1978), along the Bergseweg at Kunrade (southern Limburg, the Netherlands, out- 


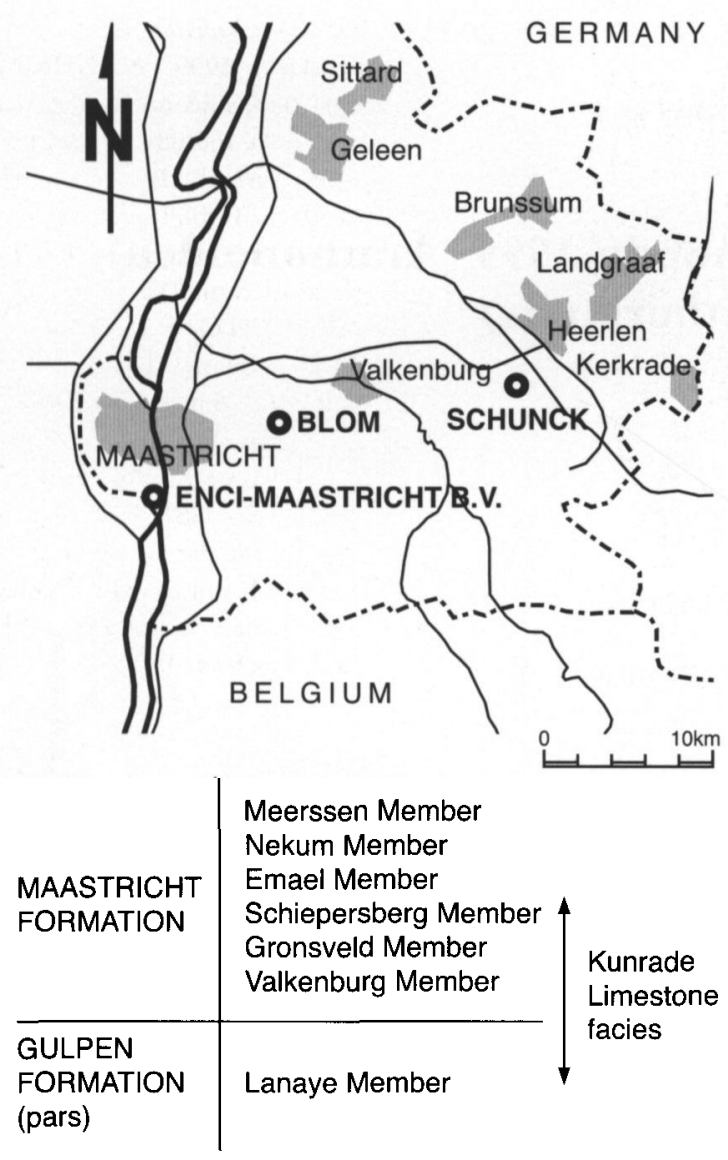

Fig. 1. Map of southern Limburg, showing localities mentioned in the text, and an outline of local lithostratigraphy.

crop 62B-11; Fig. 1). It was collected from a scree slope in November 1964 by a Mr Schidlovski. P.J. Felder \& Bless (1989, fig. 3) noted that in the Kunrade area the uppermost part of the Kunrade Limestone unit was exposed, which corresponded to the upper part of their Ecozone V, of early Late Maastrichtian age. This would correlate with benthic foram zone $\mathrm{H}$ (sensu Hofker, 1966), or the lower half of the Maastricht Formation up to the base of the Emael Member, as developed in the Maastricht area (ENCIMaastricht bv quarry) (see Fig. 1).

NHMM 2001083 (Fig. 2A) is a silicone rubber cast of an external mould of a partial phragmocone preserved in flint, from unit IVe-2 of the lower Nekum Member (Maastricht Formation) at the former Blom quarry (Berg en Terblijt; Fig. 1), collected by Martin Blom on March 17, 1983. The Nekum Member equates with Hofker's (1966) benthic foram zone $\mathrm{K}$, and is of early Late Maastrichtian age (Belemnitella junior Zone of authors) as well.

\section{Systematic palaeontology}

Repositories of specimens are as follows:

GSP - Geological Survey of Pakistan, Islamabad;
NHMM - Natuurhistorisch Museum Maastricht, Maastricht;

RGM - Nationaal Natuurhistorisch Museum/Naturalis, Leiden (formerly Rijksmuseum van Geologie en Mineralogie) (NITG-Jongmans Collection). All dimensions are given in millimetres: $\mathrm{D}$, diameter; $\mathrm{Wb}$, whorl breadth; Wh, whorl height; $U$, umbilical diameter. Figures in parentheses are dimensions as a percentage of the diameter.

Order Ammonoidea von Zittel, 1884

Suborder Ammonitina Hyatt, 1889

Superfamily Desmocerataceae von Zittel, 1895

Family Pachydiscidae Spath, 1922

Genus and subgenus Pachydiscus (Pachydiscus) von Zittel, 1884

Type species - Ammonites neubergicus von Hauer 1858, p. 12, pl. 2, figs 1-3; pl. 3, figs 1, 2, by subsequent designation of de Grossouvre, 1894, p. 177.

Pachydiscus (Pachydiscus) noetlingi Kennedy, 1999

?1861 Ammonites colligatus Binkhorst, p. 25 (partim), pl. 8 a, fig. 3 only.

?1987 Pachydiscus (Pachydiscus) cf. jacquoti Seunes, 1890; Kennedy, p. 163 (partim), pl. 15, figs 13 only (Anapachydiscus cf. jacquoti in caption).

*1999 Pachydiscus (Pachydiscus) noetlingi Kennedy, p. 648 , figs $4.9,4.10,7.4-7.6,8.4-8.7,9.1-$ 9.6, 14.4, 15.4.

Material - Holotype is GSP 1047 (Fig. 2D, E), of which NHMM 1999040 is a plaster cast; paratypes are GSP 1048-1051, all from the Upper Maastrichtian Korara Shale of Goth Haji Ismail (southern Pab Range, Pakistan). Material from the Maastrichtian type area is registered under numbers RGM NITG P.244 and NHMM 2001083.

Dimensions

\begin{tabular}{llllll}
\hline & $\mathrm{D}$ & $\mathrm{Wh}$ & $\mathrm{Wb}$ & $\mathrm{Wb}: \mathrm{Wh}$ & $\mathrm{U}$ \\
\hline GSP & 118.7 & 50.1 & 47.3 & 0.85 & 29.2 \\
1047 & $(100)$ & $(42.2)$ & $(39.8)$ & & $(24.6)$ \\
& & & & & \\
GSP & 109.0 & 50.4 & 43.4 & 0.94 & 28.3 \\
1050 & $(100)$ & $(46.2)$ & $(39.8)$ & & $(26.0)$ \\
& & & & & \\
RGM & 84.0 & 35.8 & 35.6 & 0.99 & 23.5 \\
NITG & $(100)$ & $(42.6)$ & $(42.4)$ & & $(27.9)$ \\
P.244 & & & & & \\
NHMM & $c$. & $c .33 .0$ & - & - & 24.2 \\
2001 & 77.5 & $(42.6)$ & & & $(31.2)$ \\
083 & $(100)$ & & & & \\
\hline
\end{tabular}



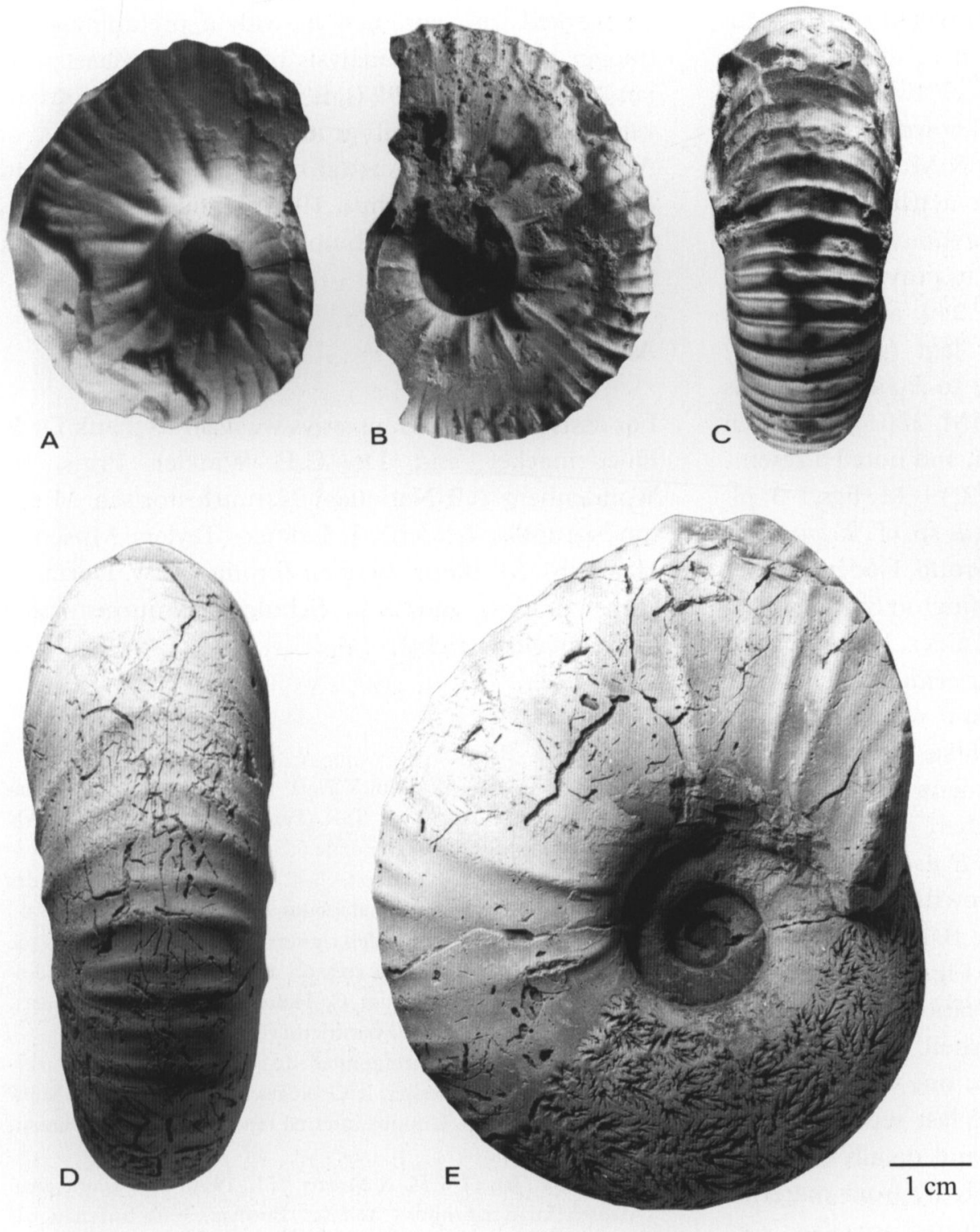

late. Body chambers not preserved; neither specimen shows the suture.

\section{Description}

Although both fragmentary, the present specimens show this species to be moderately involute, with a slightly compressed, oval whorl section (Fig. 3). The umbilicus is moderately deep, with a convex wall merging with the umbilical shoulder; the early phragmocone whorls are smooth; distant inner flank ribs occur, these are straight or slightly prorsiradiate, develop at the second growth stage, and efface on the outer flanks. Later phragmocone whorls have 13-14 primary ribs per whorl, arising at umbilical seam, flexing back across umbilical shoulder, where they are concave; straight or feebly prorsiradiate on flanks and transverse to feebly convex on venter; separated by 25 short intercalated mid- to outer flank ribs, of (sub)equal strength across venter; primary ribs strengthen progressively and become incipiently bul-
Fig. 2. Pachydiscus (P.) noetlingi Kennedy, 1999. A. NHMM 2001083 , silicone rubber cast of external mould of phragmocone, former Blom quarry (Berg en Terblijt), Maastricht Formation, basal Nekum Member (unit IVe-2); B, C RGM NITG P.244, former Schunck quarry (Bergseweg at Kunrade, outcrop 62B-11), Maastricht Formation, upper part of Kunrade Limestone facies; D, E - GSP 1047 (holotype), from the Upper Maastrichtian Korara Shale of Goth Haji Ismail (southern Pab Range, Pakistan).

\section{Discussion}

As discussed by Kennedy (1999, p. 651), P. noetling $i$ is close to $P$. jacquoti, differing from the nominate subspecies, P. j. jacquoti (see Kennedy, 1986, 1987; Ward

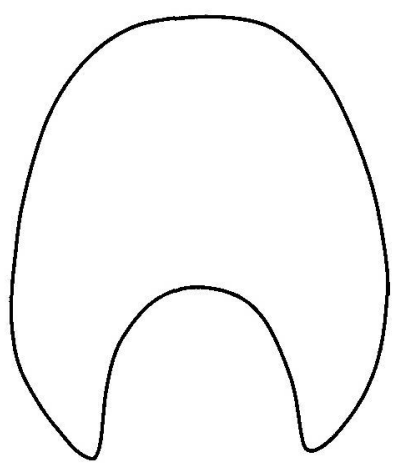

Fig. 3. Whorl section of RGM NITG P. 244 at $D=79.5 \mathrm{~mm}$. 
\& Kennedy, 1993) in retaining crowded ribs and numerous secondaries, which persist to the adult body chamber. The retention of one or two intercalated ribs to the largest diameters known distinguishes Pachydiscus $j$. australis Henderson \& McNamara, 1985 from the nominate subspecies, rib density and coarseness being quite distinct from $P$. noetlingi.

Collignon (1966) was the first to provide a description of specimen RGM NITG P.244, and referred it to $P$. neubergicus. Subsequently, Jagt (1995, p. 25) commented on the close alliance to P. jacquoti of this and the other specimen (NHMM 2001 083) then traced in the $\mathrm{M}$. Blom Collection, and noted a resemblance to what Usher (1952, p. 72, pl. 11, figs 1-3; pl. 31, fig. 1) referred to as Pachydiscus sp. cf. jacquoti Seunes, 1890, from the Nanaimo Group, Ceder District Formation, of Sucia Island (Washington State, USA). That material, however, is much older, being of Late Campanian age, as dated on other evidence (Haggart, 1989; Haggart \& Ward, 1989), and whorl section is more depressed and ornament coarser.

Although neither of the specimens before us preserve portions of the body chamber, there is a close match with the type material of $P$. noetlingi in ornament and whorl proportions of growth stages 1 and 2 . Primary and secondary ribs in the Baluchistan material appear stronger (compare e.g. Fig. 3D, E with 3B, C), but this is a matter of preservation, the Kunrade specimen retaining a silicified shell. RGM NITG P.244 shows two adnate oysters, one on the outer flank, the other (bivalved) on the last septal wall, as preserved. In whorl proportions and details of ornament, both specimens differ markedly from material referred to $P . j$. jacquoti from the same area (see e.g. Kennedy, 1987). A fragmentary phragmocone described and illustrated by Binkhorst $(1861$, p. 29, pl. 8a, fig. 3), a paralectotype of $P$. (P) colligatus (see Kennedy, 1987, p. 163), is stated to be from '.. notre craie jaune supérieure de Benzeraad près de Kunraed, et $[. .$.$] dans la carrière de cette dernière localité$ [...]'. This specimen, which was refigured by Kennedy (1987, pl. 15, figs 1-3), is from the Kunrade Limestone facies; whorl section, style of ribbing and dimensions suggest it may be referable to $P$. noetling $i$ as well.

\section{Occurrence}

Upper Maastrichtian of Baluchistan, and lower Upper Maastrichtian (Belemnitella junior Zone of authors) of southern Limburg (the Netherlands). The present record substantiates earlier interpretations of faunal immigration events during deposition of the Maastricht Formation. Although details still need to be worked out, and tied in with a preliminary sequence-stratigraphic analysis of the type Maastrichtian (Schiøler et al., 1997), it is of note that various invertebrate macrofossil groups contain elements of Afro-Arabic and/or Austral origin, e.g. trigoniid and ostreid bivalves (Malchus, 1990; Dhondt et al., 1996, work under way) and echinoids (Jagt et al., 1999; Jagt, 2000).

\section{Acknowledgements}

For assistance in various ways we wish to thank Dr P. Hoedemaeker and Dr C.F. Winkler Prins, W. Woudenberg (all Nationaal Natuurhistorisch Museum/Naturalis, Leiden), J. Leloux (Teylers Museum, Haarlem), M. Blom (Berg en Terblijt), R.W. Dortangs (Amstenrade), and A.S. Schulp (Natuurhistorisch Museum Maastricht).

\section{References}

Atabekian, A.A. \& Akopian, V.T., 1969. [Late Cretaceous ammonites of the Armenian SSR (Pachydiscidae)]. Izvestiya AN Armyanskoj SSR, Nauki o Zemle 6: 3-20 [in Russian].

Binkhorst van den Binkhorst, J.-T., 1861. Monographie des Gastéropodes et des Céphalopodes de la Craie supérieure du Limbourg, suivie d'une description de quelques espèces de Crustacés du même dépôt crétacé, avec dix-huit planches dessinées et lithographiées par C. Hohe, de Bonn. A. Muquart, Bruxelles/Muller Frères, Maastricht: vi $+83+44$ pp.

Collignon, M., 1966. Ammonites du Crétacé supérieur néerlandais, communiqués par le Geologisch Bureau voor het Mijngebied de Heerlen. Unpubl. internal report, Geologisch Bureau, Heerlen: 15 pp.

Dhondt, A.V., Jagt, J.W.M. \& Morris, N.J., 1996. The stratotypical Maastrichtian trigoniids (Mollusca, Bivalvia). Fifth International Cretaceous Symposium and Second Workshop on Inoceramids, Freiberg/Saxony, September 1996, Abstract volume: 109.

Fatmi, A.N. \& Kennedy, W.J., 1999. Maastrichtian ammonites from Balochistan, Pakistan. Journal of Paleontology 73: 641-662.

Felder, P.J. \& Bless, M.J.M., 1989. Biostratigraphy and ecostratigraphy of Late Cretaceous deposits in the Kunrade area (SouthLimburg, SE Netherlands). Annales de la Société géologique de Belgique 112: 31-45.

Felder, W.M., 1978. Ontsluitingen van de Kunrader Kalksteen. Grondboor en Hamer 32: 86-121.

Grossouvre, A. de, 1894. Recherches sur la craie supérieure, 2. Paléontologie. Les ammonites de la craie supérieure. Mémoires du Service de la Carte géologique détaillée de la France: 1-264, 39 pls. (misdated 1893).

Haggart, J.W., 1989. New and revised ammonites from the Upper Cretaceous Nanaimo Group of British Columbia and Washington State. Bulletin of the Geological Survey of Canada 396: 181221.

Haggart, J.W. \& Ward, P.D., 1989. New Nanaimo Group ammonites (Cretaceous, Santonian-Campanian) from British Columbia and Washington State. Journal of Paleontology 63: 218227.

Hauer, F. von, 1858. Über die Cephalopoden aus den Gosauschichten. Beiträge zur Paläontologie von Österreich 1: 7-14. 
Henderson, R.A. \& McNamara, K.J., 1985. Maastrichtian nonheteromorph ammonites from the Miria Formation, Western Australia. Palaeontology 28: 35-88.

Hofker, J., 1966. Maestrichtian, Danian and Paleocene Foraminifera. The Foraminifera of the type Maestrichtian in South Limburg, Netherlands, together with the Foraminifera of the underlying Gulpen Chalk and the overlying calcareous sediments; the Foraminifera of the Dansk Chalk and the overlying Greensands and Clays as found in Denmark. Palaeontographica, Suppl. A10: ii $+1-376$.

Hyatt, A., 1889. Genesis of the Arietidae. Smithsonian Contributions to Knowledge 673: $\mathrm{xi}+239 \mathrm{pp}$.

Jagt, J.W.M., 1989. Ammonites from the early Campanian Vaals Formation at the CPL quarry (Haccourt, Liège, Belgium) and their stratigraphic implications. Mededelingen van de Rijks Geologische Dienst 43: 1-33.

Jagt, J.W.M., 1995. A Late Maastrichtian ammonite faunule in flint preservation from northeastern Belgium. Mededelingen van de Rijks Geologische Dienst 53:21-47.

Jagt, J.W.M., 2000. Late Cretaceous-Early Palaeogene echinoderms and the K/T boundary in the southeast Netherlands and northeast Belgium - Part 4: Echinoids. Scripta Geologica 121: 181-375.

Jagt, J.W.M., 2002. Late Cretaceous ammonite faunas of the Maastrichtian type area. Abhandlungen der geologischen Bundesanstalt Wien 57(2001): 509-522.

Jagt, J.W.M., Burnett, J. \& Kennedy, W.J., 1995. Campanian ammonites and nannofossils from southern Limburg, the Netherlands. Mededelingen van de Rijks Geologische Dienst 53: 49-63.

Jagt, J.W.M., Deckers, M., Dhondt, A.V., Dortangs, R.W., Felder, P.J., Felder, W.M., Jäger, M., Keutgen, N., Kuypers, M., Michels, G., Reynders, J., Simon, E., van der Ham, R., van Knippenberg, P. \& van Neer, R., 1995. Preliminary report of field work at Altembroeck (NE Belgium, early Maastrichtian) by the Working Group Beutenaken/Vijlen Members. Belgische Geologische Dienst, Professional Paper 1995/1 (276): 1-20.

Jagt, J.W.M. \& Felder, W.M., 2003. The stratigraphic range of the index ammonite Pachydiscus neubergicus (von Hauer, 1858) in the Maastrichtian type area. Netherlands Journal of Geosciences 82: 261-268.

Jagt, J.W.M., van der Ham, R.W.J.M., Meuris, R. \& Indeherberge, L., 1999. A note on Salenia gr. nutrix Peron and Gauthier, 1881 (Echinoidea) from the Maastrichtian type area (southeastern Netherlands, northeastern Belgium). Journal of Paleontology 73: 663-666.

Kennedy, W.J., 1986. The ammonite fauna of the Calcaire à Baculites (Upper Maastrichtian) of the Contentin Peninsula (Manche, France). Palaeontology 29: 25-83.

Kennedy, W.J., 1987. The ammonite fauna of the type Maastrichtian with a revision of Ammonites colligatus Binkhorst, 1861. Bulletin de l'Institut royal des Sciences naturelles de Belgique, Sciences de la Terre 56 (1986): 151-267.

Kennedy, W.J. \& Jagt, J.W.M., 1998. Additional Late Cretaceous ammonite records from the Maastrichtian type area. Bulletin de l'Institut royal des Sciences naturelles de Belgique, Sciences de la Terre 68: 155-174.

Malchus, N., 1990. Revision der Kreide-Austern (Bivalvia: Pteriomorphia) Ägyptens (Biostratigraphie, Systematik). Berliner geowissenschaftliche Abhandlungen A 125 : 1-231.

Orbigny, A. d', 1850. Prodrome du paléontologie stratigraphique universelle des animaux mollusques et rayonnés, faisant suite au cours élémentaire de paléontologie et de géologie stratigraphique. Victor Masson (Paris): $1 \mathrm{x}+394 \mathrm{pp}$.

Schiøler, P., Brinkhuis, H., Roncaglia, L. \& Wilson, G.J., 1997. Dinoflagellate biostratigraphy and sequence stratigraphy of the
Type Maastrichtian (Upper Cretaceous), ENCI Quarry, The Netherlands. Marine Micropaleontology 31: 65-95.

Schlüter, C., 1867. Beitrag zur Kenntniss der jüngsten Ammoneen Norddeutschlands. A. Henry (Bonn): 36 pp., 6 pls.

Schlüter, C., 1872. Cephalopoden der oberen deutschen Kreide. Palaeontographica 21: 1-120, pls 1-35.

Seunes, J., 1890. Contributions à l'étude des céphalopodes du Crétacé supérieur de France, 1. Ammonites du Calcaire à Baculites du Cotentin. Mémoires de la Société géologique de France 1(2): $1-7$, pls 2,3 .

Seunes, J., 1892. Contribution à l'étude des céphalopodes du Crétacé supérieur de France, I. Ammonites du Calcaire à Baculites $\mathrm{du}$ Cotentin (suite), II. Ammonites du Campanien de la région sous-pyrénéenne, Département de Landes. Mémoires de la Société géologique de France 2(2): 8-22, pis 12-15.

Spath, L.F., 1922. On the Senonian ammonite fauna of Pondoland. Transactions of the royal Society of South Africa 10: 113-147.

Usher, J.L., 1952. Ammonite faunas of the Upper Cretaceous rocks of Vancouver Island, British Columbia. Bulletin of the Geological Survey of Canada 21: 1-182.

Ward, P.D. \& Kennedy, W.J., 1993. Maastrichtian ammonites from the Biscay region (France, Spain). The Paleontological Society Memoir 34: 1-58.

Zittel, K.A. von, 1884. Handbuch der Paläontologie, $1(2) 3$. Cephalopoda. R. Oldenburg (München/Leipzig): 329-522.

Zittel, K.A. von, 1895. Grundzüge der Palaeontologie (Palaeozoologie). R. Oldenburg (München/Leipzig): vii + 972 pp. 